\title{
Similarity in transcytosis of nNOS $\alpha$ in enteric nerve terminals and beta cells of pancreatic islet
}

\section{Arun Chaudhury*}

Division of Surgery, Brigham and Women's Hospital, Harvard Medical School and VA Boston HealthCare System, Boston, MA, USA

*Correspondence: arun_chaudhury@hms.harvard.edu; arunchaudhury.boston@gmail.com

Edited by:

Yeong Yeh Lee, Universiti Sains Malaysia, Malaysia

Reviewed by:

Mohammad Bashashati, University of Calgary, Canada

Keywords: nNOS, myosin Va, diabetes, dimer, LC8

Transcytosis of proteins and hydrodynamic flow of cytoplasm is a major mechanism to sustain physiology in all cells, observable from gametes (1) to mature adult cells and tissues $(2,3)$. Mammalian cells involved in secretion discretely need to respond to the environment and move components within the cells and position them at appropriate locations for secretion $(4,5)$. This process involves force generation using Gibbs free energy of hydrolysis of adenosine triphosphate (ATP). The ATPase is most often myosin, a naturally occurring cellular ATPase known for its wide role in generation of cellular force (6). The nanomechanics of transport involve the necessary target cargoes, in association with myosin and track on actin filaments, which are ubiquitous cellular cytoskeletal scaffolds of metazoan cells (7). Cellular secretion encompasses multiple physiological systems operating on wide range of time scales including the processes of exocrine and endocrine glandular secretions and neuronal secretion in response to discrete electrical field stimulation, commonly referred to as neurotransmission $(8,9)$.

Here, similarity is outlined between the mechanisms involved in gaseous nitric oxide (NO) synthesis within the enteric nerve terminals in response to an action potential (10-15) and during glucose sensing and insulin granule exocytosis by pancreatic beta cells (16-20) (Figure 1). These comparisons provide new directions to investigate physiology of insulin exocytosis in health and potential dysfunction as a pathophysiologic mechanism of diabetes mellitus. NO may perform physiological functions during insulin exocytosis from large dense core secretory vesicles
(LDCVs). Reasonable evidence and consensus exist regarding the role of NO during biphasic secretion of insulin under normal physiological conditions (16, 17, 2124). Though the exact contribution of $\mathrm{NO}$ is not well defined, incipient convincing evidence exists regarding de novo synthesized NO by neuronal nitric oxide synthase (nNOS) to maintain a pool of glucokinase in association with insulin secretory granules (25). Glucokinase, a form of lowsensitive hexokinase, catalyzes the first and rate-limiting step in conversion of glucose to a hexose phosphate, which sets a feedback balance between sensing the extracellular glucose concentration and operating this as a stimulus for insulin granules' exocytosis. It was reported from early studies that infusion of $\mathrm{L}$-arginine increases insulin release $(26,27)$, and this is disrupted in patients with non-insulin-dependent diabetes mellitus (NIDDM) (28). Incipient evidence also exists regarding the role of $\mathrm{L}$-citrulline in replenishing cellular levels of L-arginine through arginosuccinate and restoring beta cell function (29).

In the smooth muscle-en passant nerve terminal junctions in the gastrointestinal tract, inhibitory neurotransmission involves release of vesicular ATP and instantaneously synthesized gaseous NO $(30,31)$. This kind of tandem transmission involving precision release of a vesicular and a non-vesicular neurotransmitter is the one of its kind only example in the body. Importantly, the contribution of nitrergic component is critical to inhibitory neurotransmission, as loss of nitrergic synthesis results in failure of mechanical relaxations and manifestations of stasis of luminal contents like gastroparesis. NO synthesis is facilitated by the alpha isoform of
nNOS, which has the potential to bind to membrane by cysteine dimerization of its N-terminal domain with palmitoylPSD95 (13). Examples from numerous systems suggest the general feature that membrane localization of $n N O S \alpha$ is perhaps critical for its function. Though cytosolic $n N O S \alpha$ may exist as a dimer and technically can favor electron transfer during oxidation of L-arginine for NO synthesis, it seems that proximity to calcium sources such as the calcium channel may be an important requirement for membrane transposition for optimal nNOS $\alpha$ enzymatic activity (13-15). Furthermore, it has been demonstrated that cytosolic nNOS is phosphorylated at serine847, which prevents calmodulin interaction and positive allostery during neurotransmission (13, 14). Recent evidence has shown the role of unconventional motor proteins like myosin $\mathrm{Va}$ in membrane transport of $\mathrm{nNOS} \alpha$ within nerve terminals (12). Hypomorphic mutant DBA/2J mice lacking functional myosin Va shows evidence of impaired prejunctional NO synthesis and NO-mediated smooth muscle responses including slow IJP and mechanical relaxations $(11,12)$.

Reliable evidence exists that in the beta cells of the pancreas, nNOS alpha isoform exists $(17,18)$. This is seen in rat, mice, and human islets (32). nNOS alpha dimer binds to the core of insulin granules and also concentrated in the subterminal membranes (17). The beta cells also contain the light chain of dynein, LC8, earlier referred to as protein inhibitor of nNOS (PIN) (17). In enteric neuronal varicosities, LC8 facilitates nNOS-myosin Va protein interactions, confirmed independently by the traditional co-immunoprecipitation experiments and visually by proximity ligation 


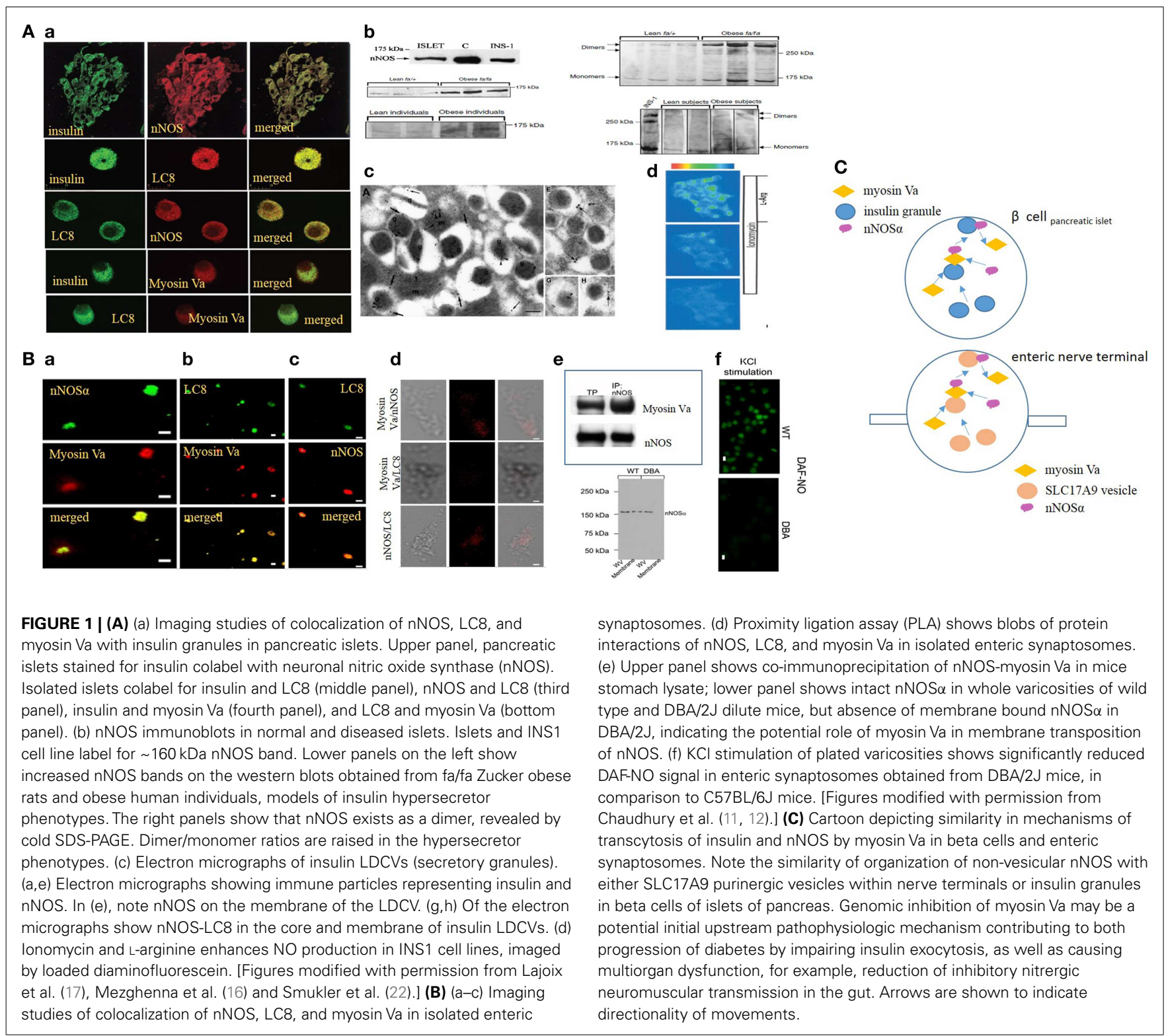

assay (PLA) $(11,12)$. Myosin Va has been demonstrated in the pancreatic beta cells, colocalized with insulin and PIN (LC8) (17). Given these comparative levels of evidence, it may be reasonable to speculate that transcellular movements of nNOS within beta cells of pancreatic islets and translocation to the subcortical zone likely involves myosin $\mathrm{Va}$, though this has never been directly demonstrated.

There are seven exonic regions $(A-G)$ in the $\mathrm{N}$-terminal portion of the tail region of myosin Va that facilitates cargo binding (33). For example, in the skin, the melanocytes have ACDE and lacks B exon. In neuronal cells, the exonic region is represented as ABE. Notably, the $\mathrm{B}$ region comprising only three bases, representing amino acids 1282-1284 of myosin Va, which represents the region for interaction of myosin Va with nNOS via LC8. In pancreatic beta cells, the exonic component is similar to brain myosin $\mathrm{Va}$ (34), providing the likelihood that nNOS-LC8 binds with myosin Va, though any direct evidence for this is lacking.

In DBA/2J mice, prejunctional nitrergic synthesis during enteric nervesmooth muscle neurotransmission has been demonstrated to be significantly reduced $(11,12)$. It seems likely that $\mathrm{NO}$ synthesis in pancreatic beta cells may be diminished in DBA/2J mice, though this remains to be tested. Whether inhibition or reduction of NO synthesis results in impaired glucose tolerance or frank diabetes is not known for DBA mice, though streptozotocin injection in DBA/2J has been used as a model of peripheral neuropathy (35). The role of myosin $\mathrm{Va}$ in secretory granule exocytosis (36), including insulin granules $(37,38)$, has been reported. It may be hypothesized that DBA phenotype should predispose to a diabetic state. As anticipated, it has been reported that DBA loci confers increased risk of diabetes (39). In the initial phases, there is a hypersecretor phenotype of C57BLKS/J 
mice created on a DBA background, with increased secretion of insulin. This has been reported to result from defects in nicotinamide nucleotide transhydrogenase (Nnt), resulting in diminution of reducing potentials and increased oxidative stress $(40,41)$, as well as other defects like that of amino acid L-arginine transporter SLC7A3, which may result in defective NO synthesis. The hypersecretor phenotype seen in the early stages of DBA/2J mice (42) may represent a prediabetic condition. This may ultimately contribute to exhaustion of insulin in the islets and frank manifestation of insulin-dependent diabetes in DBA/2J mice. Myosin Va facilitates transcellular movement of glucose transporters like GLUT4, which are important components for mobilization of glucose in the peripheral organs like the skeletal muscles and adipocytes (43-46). It is possible that the initial phases of DBA/2J might represent a prediabetic state and a condition of peripheral insulin resistance resulting from impaired or suboptimal mobilization of myosin Va-dependent glucose transporters like GLUT4 results in the hypersecretor phenotype of the pancreatic islets. Temporal studies using DBA mice shall provide insights into the progression of prediabetic state to one of frank diabetes mellitus and complications arising as a result of long-standing diabetes.

Myosin Va has been shown to facilitate both the first phase of insulin release, as well as during sustained phase when storage pool vesicles are recruited to a readily releasable pool in a non-linear dynamics $(45,46)$. This may occur due to facilitator effect on insulin-containing LDCV movement in the cell cortex. Though it has not been specifically tested, it is likely that myosin Va facilitates both secretory granule vesicular movement, as well as nNOS movement toward the cell periphery for association with insulin granules. In obese Zucker rats and islets derived from obese humans, it has been shown that these islets demonstrate a hypersecretor phenotype, and has been related to increased nNOS dimers (16). Recent observation has been made regarding significant reduction of myosin $\mathrm{Va}$ in myenteric neuronal soma and nerve varicosities of jejunum in streptozotocin-induced diabetes, likely a result of inhibition of genomic transcription of myosin $\mathrm{Va}$ (47). The reduction in myosin Va may result from reduction in its glucose-sensitive transcription factor Snail (48). It may be worthwhile to examine whether hyperglycemia globally affects this transcription factor, which in turn may affect all myosin Va-related functions including nNOS enzymatic activity during enteric nitrergic neurotransmission and insulin granule exocytosis and its regulation in beta cells of pancreas.

\section{ACKNOWLEDGMENTS}

The author wishes to thank Dr. Hemant Thatte. The author acknowledges pending support from NIDDK Diabetic Complications Consortium (Diacomp, www. diacomp.org), grant DK076169.

\section{REFERENCES}

1. Krauss J, López de Quinto S, Nüsslein-Volhard C, Ephrussi A. Myosin-V regulates oskar mRNA localization in the Drosophila oocyte. Curr Biol (2009) 19:1058-63. doi:10.1016/j.cub.2009.04.062

2. Woodhouse FG, Goldstein RE. Cytoplasmic streaming in plant cells emerges naturally by microfilament self-organization. Proc Natl Acad Sci U S A (2013) 110:14132-7. doi:10.1073/pnas. 1302736110

3. Heisenberg CP, Bellaïche Y. Forces in tissue morphogenesis and patterning. Cell (2013) 153:948-62. doi:10.1016/j.cell.2013.05.008

4. Huypens PR, Huang M, Joseph JW. Overcoming the spatial barriers of the stimulus secretion cascade in pancreatic $\beta$-cells. Islets (2012) 4:1-116. doi: $10.4161 /$ isl. 18338

5. Rutter GA. Nutrient-secretion coupling in the pancreatic islet $\beta$-cell: recent advances. Mol Asp Med (2001) 22:247-84. doi:10.1016/S0098-2997(01) 00013-9

6. Sweeney HL, Houdusse A. Structural and functional insights into the Myosin motor mechanism. Annu Rev Biophys (2010) 39:539-57. doi:10.1146/ annurev.biophys.050708.133751

7. Pollard TD, Cooper JA. Actin, a central player in cell shape and movement. Science (2009) 326:1208-12. doi:10.1126/science. 1175862

8. Trifaró JM. The 1989 Upjohn Award lecture. Cellular and molecular mechanisms in hormone and neurotransmitter secretion. Can J Physiol Pharmacol (1990) 68:1-16.

9. Aunis D, Bader MF. The cytoskeleton as a barrier to exocytosis in secretory cells. J Exp Biol (1988) 139:253-66.

10. Chaudhury A. Molecular handoffs in nitrergic neurotransmission. Front Med (2014) 1:8. doi:10. 3389/fmed.2014.00008

11. Chaudhury A, Cristofaro V, Carew JA, Goyal RK, Sullivan MP. Myosin Va plays a role in nitrergic smooth muscle relaxation in gastric fundus and corpora cavernosa of penis. PLoS One (2014) 9:e86778. doi:10.1371/journal.pone.0086778

12. Chaudhury A, He XD, Goyal RK. Myosin Va plays a key role in nitrergic neurotransmission by transporting $\mathrm{nNOS} \alpha$ to enteric varicosity membrane.
Am J Physiol Gastrointest Liver Physiol (2011) 301:G498-507. doi:10.1152/ajpgi.00164.2011

13. Chaudhury A, He XD, Goyal RK. Role of PSD95 in membrane association and catalytic activity of nNOSalpha in nitrergic varicosities in mice gut. Am J Physiol Gastrointest Liver Physiol (2009) 297:G806-13. doi:10.1152/ajpgi.00279.2009

14. Chaudhury A, Rao YM, Goyal RK. PIN/LC8 is associated with cytosolic but not membranebound nNOS in the nitrergic varicosities of mice gut: implications for nitrergic neurotransmission. Am J Physiol Gastrointest Liver Physiol (2008) 295:G442-51. doi:10.1152/ajpgi.90280.2008

15. Rao YM, Chaudhury A, Goyal RK. Active and inactive pools of nNOS in the nerve terminals in mouse gut: implications for nitrergic neurotransmission. Am J Physiol Gastrointest Liver Physiol (2008) 294:G627-34. doi:10.1152/ajpgi.00519.2007

16. Mezghenna K, Pomiès P, Chalançon A, Castex F, Leroy J, Niclauss $\mathrm{N}$, et al. Increased neuronal nitric oxide synthase dimerisation is involved in rat and human pancreatic beta cell hyperactivity in obesity. Diabetologia (2011) 54:2856-66. doi:10.1007/s00125-011-2264-8

17. Lajoix AD, Badiou S, Péraldi-Roux S, Chardès T, Dietz S, Aknin C, et al. Protein inhibitor of neuronal nitric oxide synthase (PIN) is a new regulator of glucose-induced insulin secretion. Diabetes (2006) 55:3279-88. doi:10.2337/db06-0257

18. Lajoix AD, Pugnière M, Roquet F, Mani JC, Dietz $\mathrm{S}$, Linck N, et al. Changes in the dimeric state of neuronal nitric oxide synthase affect the kinetics of secretagogue-induced insulin response. Diabetes (2004) 53:1467-74. doi:10.2337/diabetes.53. 6.1467

19. Beffy P, Lajoix AD, Masiello P, Dietz S, PéraldiRoux $S$, Chardès $T$, et al. A constitutive nitric oxide synthase modulates insulin secretion in the INS1 cell line. Mol Cell Endocrinol (2001) 183:41-8. doi:10.1016/S0303-7207(01)00610-4

20. Lajoix AD, Reggio H, Chardès T, Péraldi-Roux S, Tribillac F, Roye M, et al. A neuronal isoform of nitric oxide synthase expressed in pancreatic betacells controls insulin secretion. Diabetes (2001) 50:1311-23. doi:10.2337/diabetes.50.6.1311

21. Schmidt HH, Warner TD, Ishii K, Sheng H, Murad F. Insulin secretion from pancreatic B cells caused by L-arginine-derived nitrogen oxides. Science (1992) 255:721-3. doi:10.1126/science.1371193

22. Smukler SR, Tang L, Wheeler MB, Salapatek AM. Exogenous nitric oxide and endogenous glucosestimulated beta-cell nitric oxide augment insulin release. Diabetes (2002) 51:3450-60. doi:10.2337/ diabetes.51.12.3450

23. Vincent SR. Nitric oxide and arginine-evoked insulin secretion. Science (1992) 258:1376-8. doi: 10.1126/science.1455235

24. Spinas GA, Laffranchi R, Francoys I, David I, Richter C, Reinecke M. The early phase of glucosestimulated insulin secretion requires nitric oxide. Diabetologia (1998) 41:292-9.

25. Markwardt ML, Nkobena A, Ding SY, Rizzo MA. Association with nitric oxide synthase on insulin secretory granules regulates glucokinase protein levels. Mol Endocrinol (2012) 26:1617-29. doi:10. 1210/me.2012-1183

26. Floyd JC Jr, Fajams SS, Conn JW, Knopf RF, Rull J. Stimulation of insulin secretion by amino acids. $J$ Clin Invest (1966) 45:1487. doi:10.1172/JCI105456 
27. Smith PA, Sakura H, Coles B, Gummerson N, Proks P, Ashcroft FM. Electrogenic arginine transport mediates stimulus-secretion coupling in mouse pancreatic beta-cells. J Physiol (1997) 499:625-635.

28. Ward WK, Bolgiano DC, McKnight B, Halter JB, Porte D Jr. Diminished B cell secretory capacity in patients with noninsulin-dependent diabetes mellitus. J Clin Invest (1984) 74:1318-28. doi:10.1172/JCI111542

29. Nakata M, Yada T. Endocrinology: nitric oxidemediated insulin secretion in response to citrulline in islet beta-cells. Pancreas (2003) 27:209-13. doi: 10.1097/00006676-200310000-00001

30. Chaudhury A. Evidence for dual pathway for nitrergic neuromuscular transmission in doubt: evidence favors lack of role of ICC. Gastroenterology (2013) 145:1160-1. doi:10.1053/j.gastro.2013. 09.039

31. Gil V, Gallego D, Grasa L, Martín MT, Jiménez M. Purinergic and nitrergic neuromuscular transmission mediates spontaneous neuronal activity in the rat colon. Am J Physiol Gastrointest Liver Physiol (2010) 299:G158-69. doi:10.1152/ajpgi.00448. 2009

32. Dorff G, Meyer G, Krone D, Pozzilli P, Zühlke H. Neuronal NO synthase and its inhibitor PIN are present and influenced by glucose in the human beta-cell line CM and in rat INS-1 cells. Biol Chem (2002) 383:1357-61. doi:10.1515/BC.2002.154

33. Seperack PK, Mercer JA, Strobel MC, Copeland NG, Jenkins NA. Retroviral sequences located within an intron of the dilute gene alter dilute expression in a tissue-specific manner. EMBO J (1995) 14:2326-32.

34. Brozzi F, Diraison F, Lajus S, Rajatileka S, Philips T, Regazzi R, et al. Molecular mechanism of myosin Va recruitment to dense core secretory granules. Traffic (2012) 13:54-69. doi:10.1111/j.1600-0854. 2011.01301.x

35. Wiggin TD, Kretzler M, Pennathur S, Sullivan KA, Brosius FC, Feldman EL. Rosiglitazone treatment reduces diabetic neuropathy in streptozotocin-treated DBA/2J mice. Endocrinology (2008) 149:4928-37. doi:10.1210/en.20080869
36. Rudolf R, Kogel T, Kuznetsov SA, Salm T, Schlicker O, Hellwig A, et al. Myosin Va facilitates the distribution of secretory granules in the F-actin rich cortex of PC12 cells. J Cell Sci (2003) 116:1339-48. doi:10.1242/jcs.00317

37. Varadi A, Tsuboi T, Rutter GA. Myosin Va transports dense core secretory vesicles in pancreatic MIN6 $\beta$-cells. Mol Biol Cell (2005) 16:2670-80. doi:10.1091/mbc.E04-11-1001

38. Kögel T, Bittins CM, Rudolf R, Gerdes HH. Versatile roles for myosin $\mathrm{Va}$ in dense core vesicle biogenesis and function. Biochem Soc Trans (2010) 38:199-204. doi:10.1042/BST0380199

39. Anderson AA, Helmering J, Juan T, Li CM, McCormick J, Graham M, et al. Pancreatic islet expression profiling in diabetes-prone C57BLKS/J mice reveals transcriptional differences contributed by DBA loci, including Plagl1 and Nnt. Pathogenetics (2009) 2:1. doi:10.1186/ 1755-8417-2-1

40. Aston-Mourney K, Wong N, Kebede M, Zraika S, Balmer L, McMahon JM, et al. Increased nicotinamide nucleotide transhydrogenase levels predispose to insulin hypersecretion in a mouse strain susceptible to diabetes. Diabetologia (2007) 50:2476-85. doi:10.1007/s00125-0070814-x

41. Freeman H, Shimomura K, Horner E, Cox RD, Ashcroft FM. Nicotinamide nucleotide transhydrogenase: a key role in insulin secretion. Cell Metab (2006) 3:35-45. doi:10.1016/j.cmet.2005. 10.008

42. Andrikopoulos S, Massa CM, Aston-Mourney K, Funkat A, Fam BC, Hull RL, et al. Differential effect of inbred mouse strain (C57BL/6, DBA/2, 129T2) on insulin secretory function in response to a high fat diet. J Endocrinol (2005) 187:45-53. doi:10.1677/joe.1.06333

43. Sun Y, Chiu TT, Foley KP, Bilan PJ, Klip A. Myosin Va mediates Rab8A-regulated GLUT4 vesicle exocytosis in insulin-stimulated muscle cells. Mol Biol Cell (2014) 25:1159-70. doi:10.1091/mbc.E13-080493

44. Chen Y, Wang Y, Zhang J, Deng Y, Jiang L, Song E, et al. Rab10 and myosin-Va mediate insulinstimulated GLUT4 storage vesicle translocation in adipocytes. J Cell Biol (2012) 198:545-60. doi:10. 1083/jcb.201111091

45. Yoshizaki T, Imamura T, Babendure JL, Lu JC, Sonoda N, Olefsky JM. Myosin 5a is an insulinstimulated Akt2 (protein kinase Bbeta) substrate modulating GLUT4 vesicle translocation. $\mathrm{Mol}$ Cell Biol (2007) 27:5172-83. doi:10.1128/MCB. 02298-06

46. Karlsson HK, Chibalin AV, Koistinen HA, Yang J, Koumanov F, Wallberg-Henriksson H, et al. Kinetics of GLUT4 trafficking in rat and human skeletal muscle. Diabetes (2009) 58:847-54. doi:10.2337/ db08-1539

47. Chaudhury A, Miranda-Neto MH, Zanoni JN. Myosin Va but not $n N O S \alpha$ is significantly reduced in jejunal musculomotor nerve terminals in diabetes mellitus. Front Med (2014) 1:17. doi:10.3389/ fmed.2014.00017

48. Lan L, Han H, Zuo H, Chen Z, Du Y, Zhao W, et al. Upregulation of myosin Va by Snail is involved in cancer cell migration and metastasis. Int J Cancer (2010) 126:53-64. doi:10.1002/ijc.24641

Conflict of Interest Statement: The author declares that the research was conducted in the absence of any commercial or financial relationships that could be construed as a potential conflict of interest.

Received:06 May 2014; paperpending published: 15 May 2014; accepted: 15 July 2014; published online: 31 July 2014.

Citation: Chaudhury A (2014) Similarity in transcytosis of $n N O S \alpha$ in enteric nerve terminals and beta cells of pancreatic islet. Front. Med. 1:20. doi: 10.3389/fmed.2014.00020

This article was submitted to Gastroenterology, a section of the journal Frontiers in Medicine.

Copyright (c) 2014 Chaudhury. This is an open-access article distributed under the terms of the Creative Commons Attribution License (CC BY). The use, distribution or reproduction in other forums is permitted, provided the original author(s) or licensor are credited and that the original publication in this journal is cited, in accordance with accepted academic practice. No use, distribution or reproduction is permitted which does not comply with these terms. 